\title{
0 problemach zdrowotnych magnackich dzieci w XVIII w. na przykładzie potomstwa Michała Kazimierza Radziwiłła zw. „Rybeńko" i Anny z Mycielskich Radziwiłłowej
}

Słowa kluczowe: Radziwiłłowie, dzieci, choroby, dolegliwości

Życie oraz działalność polityczna Michała Kazimierza Radziwiłła zw. „Rybeńko” (1702-1762) hetmana wielkiego litewskiego i wojewody wileńskiego (od 1744 r.) cieszy się dużym zainteresowaniem ze strony badaczy zarówno polskich, jak i litewskich ${ }^{1}$. W ostatnich kil-

\footnotetext{
${ }^{1}$ V. Veličkaitè, Mykolo Kazimiero Radvilos Žuvelès piligrimystė XVIII a., „Liaudies kultūra” 2017, nr 5, s. 18-32; taż, Apie Radvilos Žuvelès m eilę Uršulei. Dienoraščio liudijimai, „Liaudies kultūra” 2017, nr 2, s. 46-50; taż, Mykolo Kazimiero Radvilos, vadinamo Žuvele (1702-1762) dienoraštis: tarp itinerarijo ir egodokumento, Bibliotheca Lituana IV: Privačioji raštija ir egodokumentinis paveldas, 2017, s. 105-212; taż, Lietuvos Didžiosios Kunigaikštystès didiko Mykolo Kazimiero Radvilos-Žuvelès kelionès jo dienoraščio duomenimis, „Darbai ir Dienos” 2015, nr 64, s. 29-47; K. Zuba, O tym jak „Rybeńkę” leczono. Kuracje i zabiegi medyczne Michała Kazimierza Radziwiłta (1702-1762), „Medycyna Nowożytna. Studia nad Kulturą Medyczną" 2001, t. 8, z. 1, s. 89-110; tenże, Michat Kazimierz Radziwiłt (1702-1762) - portret psychologiczny, „Medycyna Nowożytna. Studia nad Kulturą Medyczną” 2002, t. 9, z. 1-2, s. 53-84; Podróże litewskiego magnata do Gdańska, Cztuchowa, a nawet i dalej... Fragmenty „Diariusza” Michała Kazimierza Radziwiłła „Rybeńki” z lat 1721, 1737 i 1752, wyd. J. Dygdała, Warszawa 2013; R. Jan-
} 
kudziesięciu latach w centrum badań znalazły się również obie żony tego wpływowego magnata ${ }^{2}$. Przypomnijmy, że pierwszą z nich była ukochana przez niego i poślubiona w 1725 r., wbrew woli apodyktycznej i despotycznej matki, Franciszka Urszula z Wiśniowieckich (1705-1753) ${ }^{3}$, późniejsza dramatopisarka, twórczyni nieświeskiego teatru; drugą zaś skromna, pochodząca ze szlacheckiej rodziny wielkopolskiej, 25-letnia wdowa po Leonie Michale Radziwille (1722-1751), Anna z Mycielskich Radziwiłłowa (1729-1771)4.

Pierwsza, w trakcie trwającego 28 lat pożycia małżeńskiego, jak ustaliła Karyna Wierzbicka-Michalska, w ciążę zachodziła 25 razy.

kowski, Śmierć matki i bliskich Michała Kazimierza Radziwiłła „Rybeńki” (1702-1762) w świetle jego diariusza, „Miscellanea Historico-Archivistica” 2015, t. 22, s. 202-217; A. Mariani, Podróż zagraniczna Michała Kazimierza Radziwiłła „Rybeńki” (1721-1723). Między tożsamościa rodowa a poczuciem przynależności do arystokracji europejskiej, [w:] M. Dębowski, A. Grześkowiak-Krwawicz, M. Zwierzykowski (red.), Europejski wiek osiemnasty: uniwersalizm myśli, różnorodność dróg, Kraków 2013, s. 211-220; J. Pietrzak, Dziedzic królewskiej purpury. Stowo i obraz w propagandowych działaniach Michała Kazimierza Radziwiłła „Rybeńki” względem przejęcia dziedzictwa Sobieskich, „Zeszyty Naukowe Towarzystwa Doktorantów UJ. Nauki Społeczne” 2016, nr 4, z. 3, s. 99-131.

${ }^{2}$ E. Suchodolska, Radziwiłłowski tłok pieczętny z drugiej połowy XVIII wieku, ,Studia Źródłoznawcze" 1997, t. 36, s. 89-100; B. Judkowiak, Arystokratyczna tożsamość książąt nieświeskich w świetle obrazów literackich i teatralnych. W kręgu twórczości Franciszki Urszuli Radziwiłłowej, [w:] Socialiniu tapatumu reprezentacijos Lietuvos Didžiosios Kunigaikštystès kultūroje, t. 4, Vilnius 2010, s. 433-436; taż, Franciszka Urszula Radziwiłłowa - w poszukiwaniu własnego głosu. Propozycje interpretacyjne, dokumentacyjne i edytorskie, Poznań 2013; B. Manyś, Radości i troski Anny z Mycielskich Radziwiłłowej w listach do męża Michała Kazimierza Radziwiłła „Rybeńki”, [w:] B. Popiołek, U. Kicińska, A. Słaby (red.), Kobiece kręgi korespondencyjne w XVII-XIX wieku, Warszawa 2016, s. 171-185; A. Jakuboszczak, B. Manyś, Obraz małżeństwa Anny z Mycielskich i Michała Kazimierza Radziwiłła „Rybeńki” w listach „drugiej pani na Nieświeżu” z lat 1754-1762, [w:] B. Manyś, M. Zwierzykowski (red.), Wokót Wielkiego Księstwa Litewskiego i jego tradycji, Poznań 2016, s. 185-200; B. Manyś, „Jak się ty tam dziś będziesz weselić, to i ja tu będę wesoła”. O świętach i świętowaniu w korespondencji Anny z Mycielskich Radziwiłłowej z lat 1754-1762, [w:] E. Kościk, F. Wolański, R. Żerelik (red.), Staropolski oglad świata. Nulla dies sine linea. Księga jubileuszowa dedykowana profesorowi Bogdanowi Rokowi w 70. rocznice urodzin, Torun 2017, s. 159-172; J. Bajer, A. Mariani, Macocha idealna: aktywność Anny Luizy z Mycielskich Radziwiłłowej w świetle francuskiej korespondencji dyplomatycznej (1764-1765), „Studia Europaea Gnesnensia” 2014, t. 10, s. 281-312; D. Fesser, Nieznany wiersz Anny z Mycielskich Radziwiłtowej, „Terminus” 2016, t. 18, z. 3(40), s. 287-299; M.E. Kowalczyk, „Żona śliczna, poczciwa $i$ wszelkich cnót petna", czyli historia życia Anny Ludwiki z Mycielskich u boku dwóch Radziwiłtów (Leona Michała, a po jego śmierci Michała Kazimierza „Rybeńko”), [w:] M. Nagielski, K. Żojdź (red.), Radziwiłtowie w służbie Marsa, Warszawa 2017, s. 321-333.

${ }^{3}$ K. Wierzbicka-Michalska, Radziwiłłowa Franciszka Urszula (1705-1753), Polski Słownik Biograficzny [dalej PSB], t. 30, Wrocław-Warszawa-Kraków-Gdańsk-Łódź 1987, s. 388-390. Zob. też B. Judkowiak, Franciszka Urszula Radziwiłłowa - w poszukiwaniu własnego głosu. Propozycje interpretacyjne, dokumentacyjne i edytorskie, Poznań 2013.

${ }^{4}$ H. Dymnicka-Wołoszyńska, Radziwiłłowa Anna Ludwika (1729-1771), PSB, t. 30, s. $387-388$. 
O problemach zdrowotnych magnackich dzieci w XVIII w. na przykładzie...

W ich wyniku na świat przyszło jedynie siedmioro dzieci: trzech chłopców [Michał Krzysztof (1727-1729), bliźniacy Janusz Tadeusz (1734-1750), Karol Stanisław zw. „Panie Kochanku” (1734-1790)] oraz cztery dziewczynki [Anna, Ludwika, Teofila (1738-1818), Katarzyna Karolina (1740-1789)]. Wieku dorosłego dożyło tylko troje z nich, a mianowicie Karol Stanisław zw. „Panie Kochanku”, późniejszy wojewoda wileński, marszałek generalny konfederacji radomskiej, ordynat nieświeski ${ }^{5}$, a także dwie jego siostry Teofila ${ }^{6}$ oraz Katarzyna Karolina ${ }^{7}$. Pozostałe ciąże zakończyły się poronieniami.

Druga żona, Anna z Mycielskich, podczas trwającego ponad 8 lat małżeństwa w ciążę zachodziła siedmiokrotnie. Sześciokrotnie doszło do ich rozwiązania. W wyniku porodów na świat przyszły zdrowe dzieci - pięć córek ${ }^{8}$ oraz jeden syn ${ }^{9}$. Wieku dorosłego dożyło czworo z nich, a mianowicie: syn Hieronim Wincenty, Weronika - późniejsza żona Franciszka Stanisława Czapskiego, Maria Wiktoria, żona Benedykta Morykoniego, oraz Józefa, żona najpierw Ksawerego Massalskiego, a następnie Michała Grabowskiego ${ }^{10}$.

Gdy ma się na uwadze ustalenia Marzeny Liedke, stwierdzić należy, że liczba dzieci, które osiągnęły wiek dorosły zarówno z pierwszego małżeństwa „Rybeńki”, jak i drugiego, przekroczyła średnią liczbę dzieci wyliczoną przez nią dla rodzin magnackich W. Ks. Litewskiego. Według badaczki z pierwszego małżeństwa wiek ten osiągało 2,3 dziecka na parę, a w kolejnych 1,4 dziecka $^{11}$. W przypadku dzieci poczętych przez Michała Kazimierza Radziwiłła „Rybeńkę” parametry te są nieco wyższe. Warto zauważyć, że płodność par małżeńskich na terenach W. Ks. Litewskiego w XVIII w. (zwłaszcza w jego pierwszej połowie) była znacznie wyższa od płodności np. arystokracji angielskiej czy francuskiej ${ }^{12}$. Prawdopodobnie taki stan rzeczy, w przy-

5 J. Michalski, Radziwitt Karol Stanisław zw. Panie Kochanku (1734-1790), PSB, t. 30, s. $248-262$.

“H. Dymnicka-Wołoszyńska, Radziwitt Michał Kazimierz zw. „Rybeńko” (17021762), PSB, t. 30, s. 305.

7 Tamże.

8 Tamże. W dzieciństwie zmarła Barbara Jadwiga Mametta Franciszki Urszula (1757-1758).

9 Tamże.

${ }^{10}$ H. Dymnicka-Wołoszyńska, Radziwiłt Michał Kazimierz..., dz. cyt., s. 305.

${ }_{11}$ M. Liedke, Demografia rodziny magnackiej w Wielkim Księstwie Litewskim na tle elit zachodnioeuropejskich. Wybrane problemy, „Przeszłość Demograficzna Polski” 2015, t. 37, nr 1, s. 56.

${ }_{12}$ Tamże, s. 58. Zob. też: J.R. Brink, Female Scholars: A Tradition of Learned Women Before 1800, Montreal 1980; C. Gray, Women Writers and Public Debate in 17th-Century Britain, Palgrave Macmillan 2007; H. Smith, Reason's disciples: seventeenth-century 
padku Anglii czy Francji, wynikał ze starzenia się tamtejszych rodów oraz bardzo bliskich pokrewieństw zachodzących między nimi, co jak wiemy, odgrywało duże znaczenie dla płodności i stanu zdrowia dzieci. Inną kwestią było świadome ograniczanie przez kobiety ciąż, z powodu z jednej strony zmęczenia wydawaniem na świat dużej liczby dzieci, z drugiej zaś zagrożenia, jakie niosły kolejne porody, zwłaszcza wśród tych, które oczekiwały potomstwa w dojrzałym wieku.

Duża liczba ciąż w XVIII-wiecznych rodzinach magnackich W. Ks. Litewskiego nie powinna budzić zdziwienia ${ }^{13}$. Każdy „stan błogosławiony" kobiety dla magnata był nadzieją na powicie zdrowego i silnego syna, który miał stanowić przedłużenie linii rodowej, zachowanie dziedzicznej własności oraz sławy rodu. Kwestię tę najlepiej oddają słowa Anny, która podczas jednych z urodzin „Rybeńki”, składając mu w liście życzenia, wyrażała nadzieję ,synów z piętnastu, z których żebyś doczekał wnucząt i prawnucząt" ${ }^{14}$. To, jak istotne dla ówczesnej kobiety funkcjonującej w strukturach magnackich było powicie syna, możemy wywnioskować z innego jej listu, w którym użalając się nad sobą, „wszystko córki rodzę, to mnie już przestawasz kochać”, zapewniała jednocześnie męża, że „,jeżeli o to idzie, będę się koniecznie starała wszelakiemi sposobami żebym syna miała"15. Męski potomek był ważny nie tylko dla ojca, w oczach którego stanowił dumę oraz potencjalnego dziedzica fortuny; miał on także niebywałe znaczenie dla matki, w przypadku której potwierdzał, a niekiedy nawet określał jej pozycję $\mathrm{w}$ rodzinie.

Podkreślić należy fakt, że tak liczne ciąże nie były jedynie efektem chęci powicia syna czy raczej synów. Wynikały także ze świadomości, że nie każde narodzone dziecko przeżyje okres dzieciństwa i dożyje dorosłości. Konieczne zatem było zrobienie wszystkiego, aby wiek dorosły osiągnęła jak największa ich liczba. Było to jedno z najtrudniejszych zadań, z jakimi zmagali się rodzice w całej ówczesnej Rzeczypospolitej

English feminists, Chicago \& London 1982; S. Stuurman, François Poulain de la Barre and the Invention of Modern Equality, Cambridge, MA and London 2004; E. de Goncourt, J. de Goncourt, La Femme au XVIIIe siècle, Paris 1882; J.-C. Martin, La Révolte brisée. Femmes dans la Révolution française et l'Empire, Paris 2008.

${ }^{13}$ Dla porównania Barbara Sanguszkowa (1718-1791) w ciągu piętnastoletniego pożycia małżeńskiego z Pawłem Karolem Sanguszką (1680-1750) urodziła jedenaścioro dzieci, w tym raz na świat przyszły bliźnięta, przeżyło tylko jedno z nich, zob. A. Jakuboszczak, Sarmacka dama: Barbara Sanguszkowa (1718-1791) i jej salon towarzyski, Poznań 2008, s. 49.

${ }^{14}$ List z Połonki, 29 IX 1754, Archiwum Główne Akt Dawnych [dalej AGAD], Archiwum Radziwiłłów [AR], dz. IV, sygn. 613, nr 63, k. 35.

${ }^{15}$ List z Nieświeża, 4 XII 1757, AGAD, AR, dz. IV, sygn. 616, nr 220, k. 54. 
O problemach zdrowotnych magnackich dzieci w XVIII w. na przykładzie...

Obojga Narodów, bez względu na przynależność stanową. O ile dziecko przeżyło szczęśliwie poród, o tyle po przyjściu na świat pojawiały się powikłania, które często były następstwem trudnego lub charakteryzującego się nieprawidłowym przebiegiem rozwiązania, noworodki zapadały na choroby zakaźne grasujące wówczas na terenach Rzeczypospolitej Obojga Narodów. Do tego dochodziło jeszcze kilka innych czynników, a mianowicie brak właściwej higieny kobiet rodzących oraz będących w połogu, słaba znajomość ciała rodzącej i jej fizjologii, co utrudniało w sposób znaczący „prowadzenie” ciąży, jak i jej rozwiązanie, nieprawidłowe żywienie, brak właściwej opieki ze strony matki lub mamki, a w przypadku rodzin uboższych możliwości (a raczej należałoby powiedzieć brak możliwości) wykarmienia pociech, które przyszły na świat (dotyczyło to zwłaszcza kolejnych dzieci w licznej już rodzinie). Wymienione wyżej wskaźniki sprawiały, że cud narodzin przemieniał się w cud przeżycia i walki o osiągnięcie wieku dorosłego, a więc 18 lat ${ }^{16}$. Warto dodać, że jak dotąd nie dysponujemy danymi, które pozwoliłyby nam przeanalizować w sposób szczegółowy zagadnienie śmiertelności magnackich dzieci w XVIII w.

W niniejszym artykule chciałabym przedstawić i przeanalizować problemy zdrowotne, z jakimi zmagały się dzieci jednego z najbogatszych i najbardziej wpływowych ludzi w XVIII-wiecznej Rzeczypospolitej. Analizie poddane zostaną choroby, które dotykały potomstwo Anny z Mycielskich Radziwiłłowej i jej męża Michała Kazimierza, zwanego „Rybeńką". Uwagę skupię nie tylko na charakterystyce dolegliwości, które występowały u Radziwiłłowych latorośli. Przeanalizowane zostaną również wzmianki źródłowe informujące nas o ich objawach, przebiegu, rodzaju zastosowanego leczenia oraz zapobieganiu nawrotom.

Warto zauważyć, że jak dotąd w historiografii polskiej i litewskiej zagadnienia związane z kondycją zdrowotną najzamożniejszych były analizowane $\mathrm{w}$ kontekście $\mathrm{z}$ jednej strony poszczególnych jednostek np. Jana Sobieskiego czy Barbary Radziwiłłówny ${ }^{17}$, z drugiej zaś

16 Tyle należało mieć lat, zgodnie ze statutami litewskimi (i kolejnymi ich kodyfikacjami), aby móc założyć własną rodzinę, zob. M. Liedke, Demografia rodziny magnackiej, s. 4.

${ }_{17}$ W. Ziembicki, Zdrowie i niezdrowie Jana Sobieskiego. Studium historyczno-lekarskie z uwzględnieniem nieznanego diariusza, „Archiwum Historii i Filozofii Medycyny oraz Historii Nauk Przyrodniczych" 1930, cz. 1, t. X, z. 2, s. 194-225; Z. Kuchowicz, Przyczyny śmierci Barbary Radziwiłłówny, „Archiwum Historii Medycyny” 1975, t. 38, z. 2, s. 121-133; W. Kaczorowski, Choroby i prawdopodobna przyczyna zgonu Zygmunta III Wazy, „Archiwum Historii Medycyny” 1982, t. 45, z. 1/4, s. 45-54; tenże, Choroby i prawdopodobne przyczyny śmierci żon Zygmunta III Wazy - Anny i Konstancji, „Studia Historyczne" 1993, z. 3, s. 287-296. 
zbiorowości, jaką stanowiła magnateria ${ }^{18}$. W odniesieniu do rodu Radziwiłłów dysponujemy szczegółową analizą stanu zdrowotnego oraz przebytych chorób przedstawicieli tego rodu z linii birżańskiej i dubińskiej ${ }^{19}$. Podkreślić należy, że wydana niedawno praca Raimondy Ragauskienè jest jedną z nielicznych, o ile nie jedyną, w której „,schodzą się" niejako badania historyczne z szeroko zakrojoną analizą stanu medycznego omawianych przykładów. Na gruncie historiografii polskiej pewne ustalenia o podobnym charakterze poczynił Krzysztof Zuba, analizując stan zdrowotny i psychiczny Bogusława Radziwiłła (1620-1669) ${ }^{20}$ oraz Michała Kazimierza Radziwiłła „Rybeńki”21. Problematyka ta nie została jednak przebadana w odniesieniu do Radziwiłłowskich dzieci.

Gdy rozważa się zagadnienia związane $\mathrm{z}$ analizą stanu zdrowia potomstwa jednego z najważniejszych przedstawicieli ówczesnej sceny politycznej, w pierwszej kolejności należy postawić pytanie, jakie możliwości badawcze $\mathrm{w}$ zakresie tak sformułowanego problemu daje materiał źródłowy. Wydaje się, że w przypadku najzamożniejszych sprawa jest nieco ułatwiona. Informacje o zgonach (niekiedy także ich przyczynach) najmłodszych pociech były dość skrupulatnie odnotowywane, czy to na kartach diariuszy, pamiętników, czy też przechowywanych sylwach, a niekiedy nawet $\mathrm{w}$ utworach panegirycznych. W przypadku dzieci Michała Kazimierza Radziwiłła dysponujemy zarówno diariuszem spisanym przez „Rybeńkę”22, którego oryginał

\footnotetext{
${ }^{18}$ E. Rostworowski, Zdrowie i niezdrowie polskich magnatów $w$ XVI-XVIII $w$., „Kwartalnik Historyczny” 1969, R. 76, z. 4, s. 865-886; tenże, Egzemplifikacja i statystyka a „postępujaca degeneracja” magnaterii, „Kwartalnik Historyczny” 1971, R. 78, z. 1, s. 258-260; Z. Kuchowicz, Z badañ nad stanem biologicznym społeczeństwa polskiego od schytku XVI do końca XVIII w., Łódź 1972; tenże, Jeszcze o zdrowiu i niezdrowiu magnatów XVII-XVIII w., „Kwartalnik Historyczny” 1970, R. 77, z. 2, s. 394-402.

${ }^{19}$ R. Ragauskienè, Mirties nugalèti nepavyko: Biržu ir Dubingiu kunigaikščiu Radvilu biologine istorija (XV a. pabaiga-XVII a.), Vilnius 2017.

${ }^{20}$ K. Zuba, Bogusław Radziwitt (1620-1669) - portret psychofizyczny magnata w świetle listów i pamiętników, „Medycyna Nowożytna. Studia nad Kulturą Medyczną” 1998 , t. 5, z. 1, s. 113-136.

${ }^{21}$ K. Zuba, O tym jak „Rybeńkę” leczono..., dz. cyt., s. 89-110; tenże, Michat Kazimierz Radziwitt (1702-1762), dz. cyt., s. 53-84.

${ }^{22}$ Diariusz Michała Kazimierza Radziwiłła „Rybeńki”, AGAD, AR, dz. VI, sygn. II-80a (dalej: Diariusz Michała Kazimierza Radziwiłła). Od dawna jest on przedmiotem badań prowadzonych zarówno przez historyków polskich, jak i zagranicznych, zob. Na Uniwersytecie Witolda Wielkiego w Kownie powstaje rozprawa doktorska pt. $L D K$ didiko pasaulèvaizdis baroko ir Apšvietos vertybiu sankirtos laikotarpiu: M.K. Radvila „Žuvelè” (1702-1762) [Światopogląd magnata Wielkiego Księstwa Litewskiego między Barokiem a Oświeceniem: Michał Kazimierz Radziwiłt zwany Rybeńko (1702-1762)], której autorką jest Vika Veličkaite, a promotorem doc. dr. Liudas Glemža. Diariusz doczekał się częściowego opracowania i opublikowania, zob. Podróże litewskiego ma-
} 
O problemach zdrowotnych magnackich dzieci w XVIII w. na przykładzie...

znajduje się w zbiorach Archiwum Głównego Akt Dawnych, jak i korespondencją Anny z Mycielskich ${ }^{23}$ przechowywaną w tym samym ośrodku archiwalnym, która $\mathrm{z}$ punktu widzenia analizowanego zagadnienia jest szczególnie cenna. Druga „pani na Nieświeżu” słała do swego małżonka niekiedy po klika listów dziennie, w których donosiła o troskach i radościach dnia codziennego ${ }^{24}$. Annie, podobnie jak wcześniej Franciszce Urszuli, najwięcej zmartwień przysparzały częste nieobecności męża wynikające $\mathrm{z}$ pełnionych przez niego funkcji politycznych i wojskowych. Sen z powiek spędzał jej również strach o zdrowie ukochanego oraz o jego życie, a także lęk o zdrowie zarówno dzieci „Rybeńki” pochodzących z pierwszego małżeństwa, jej dzieci zrodzonych z Leona Michała, jak i pociech z drugiego związku ${ }^{25}$.

Zgromadzony materiał źródłowy pozwala stwierdzić, że Radziwiłłowskie dzieci najczęściej zmagały się z chorobami zakaźnymi, układu oddechowego, układu pokarmowego oraz krótkoterminowymi infekcjami niewiadomego pochodzenia. $Z$ uwagi na lakoniczność większości doniesień niemożliwe jest określenie częstotliwości zachorowań. $\mathrm{Z}$ całą pewnością można stwierdzić, że to miesiące jesienno-zimowe oraz wczesnowiosenne były tymi, w trakcie których występowało najwięcej problemów zdrowotnych. Taki stan rzeczy wynikał nie tylko ze zmiany temperatury następującej we wskazanych okresach, ale także przesilenia, które mogło doprowadzić do osłabienia organizmu. Brak właściwej diety również sprzyjał rozwojowi różnych infekcji.

gnata do Gdańska, Człuchowa, a nawet $i$ dalej... Na jego podstawie powstał szereg artykułów, zob. A. Mariani, O XVIII-wiecznych praktykach łowieckich $w$ świetle diariusza księcia Michała Kazimierza Radziwiłła „Rybeńki”, [w:] T.J. Żuchowski (red.), Europejskie tradycje towieckie. Tom wydany z okazji III Międzynarodowego Kongresu Kultury Łowieckiej, Warszawa 2014, s. 67-77; T. Zielińska, Więź rodowa domu Radziwiłtowskiego w świetle diariusza Michała Kazimierza Radziwiłła „Rybeńki”, Miscellanea Historico-Archivistica, 3: Radziwiłtowie XVI-XVIII wieku. W kręgu polityki i kultury, Warszawa-Łódź 1989, s. 175-190; P. Gad, Zagraniczna podróż młodego magnata w świetle diariusza Michała Kazimierza Radziwitła „Rybeńki”, [w:] B. Mazurkowa (red.), Codzienność i niecodzienność oświeconych, cz. 2: W rezydencji, w podróży i na scenie publicznej, Katowice 2013, s. 77-87; A. Muszyńska, Starania Michała Kazimierza Radziwiłła „Rybeńki” o rękę Marii Zofii z Sieniawskich, [w:] B. Mazurkowa (red.), Codzienność i niecodzienność..., dz. cyt., s. 89-100.

${ }^{23}$ Korespondencja Anny z Mycielskich Radziwiłłowej liczy 560 listów (według inwentarza archiwalnego), zob. AGAD, AR, dz. IV, teka 42, kop. 612-615, teka 43, kop. 616-621. Dla porównania korespondencja Franciszki Urszuli z Wiśniowieckich Radziwiłłowej liczy 1347 listów (według inwentarza archiwalnego), zob. AGAD, AR, dz. IV, teka 49, kop. 657-660; teka 50, kop. 661-664, teka 51, kop. 665-668, teka 52, kop. 669-670.

${ }^{24}$ B. Manyś, Radości i troski Anny..., dz. cyt.

${ }_{25}$ Anna ze związku z Leonem Michałem Radziwiłłem miała córkę Teofilę oraz trzech synów Mikołaja, Michała oraz Macieja. 
Szczególnie niebezpieczne, zwłaszcza dla dzieci, które przecież charakteryzują się obniżonym układem odpornościowym, były ospa (trudno określić, czy wietrzna czy prawdziwa) oraz odra - choroby zakaźne zbierające w XVII i XVIII w. obok dżumy największe żniwo. $Z$ korespondencji Anny wynika, że osłabienie noworodka lub niemowlaka $\mathrm{z}$ reguły wiązano $\mathrm{z}$ wystąpieniem jednej lub drugiej choroby. Druga „pani na Nieświeżu” w liście słanym do męża 21 października 1756 r. pisała „Kostusia troszki dziś zdrowsza, ale bardzo słaba, rozumiałam, że będzie ospa albo odra, ale może na zęby" ${ }^{26}$. Pomimo że po narodzinach opiekę nad dzieckiem przejmowała mamka, powyższy fragment dowodzi, że Anna nie traciła kontaktu z dziećmi, a obserwowała swoje pociechy bacznie. Spadek ich nastroju, apatyczność były dla matki sygnałem wyraźnie niepokojącym. Opisywany przypadek dotyczył zachorowania na ospę półrocznej Konstancji Taidy Wincenty Elżbiety, która na świat przyszła 20 kwietnia tego samego roku ${ }^{27}$. Osłabienie niemowlaka musiało wzbudzić duży strach u Anny. W kolejnych listach czytamy o rozwoju choroby. Dziesięć dni od podzielenia się z mężem swoimi niepokojami Anna informowała Michała o wystąpieniu u Kostusi pierwszych objawów, mianowicie kataru oraz infekcji oczu, które nie wskazywały pierwotnie, że dziecko zmagać się będzie $\mathrm{z}$ tą niezwykle niebezpieczną chorobą ${ }^{28}$. 3 listopada $\mathrm{w}$ liście słanym do wojewody wileńskiego donosiła o poprawie zdrowia córki, pisząc jednocześnie, że katar nie ustąpił i „mocno się osypało w dole" 29 . Ospa charakteryzuje się m.in. tym, że plamkowo-grudkowa wysypka pojawia się przede wszystkim na twarzy oraz kończynach, a także w miejscach intymnych (na śluzówkach), co prawdopodobnie zasygnalizowała Radziwiłłowa. Podobną wiadomość przekazała „Rybeńce” 7 listopada, pisząc, że „Kostusia jest w sobie zdrowsza, ale $\mathrm{w}$ dole mocno chora, gdyż ją plastrami okładają [...]"30. Anna nie wyjaśniła, jakich plastrów użyto do złagodzenia bólu i zapewne świądu. Brak wyjaśnień mógł wynikać $\mathrm{z}$ faktu, że były one w powszechnym użyciu ${ }^{31}$. W kolejnych listach czytamy o dalszym postępie choroby. Anna bardzo chciała wierzyć w poprawę stanu zdrowia ukochanej córeczki, opisywane przez nią objawy i dolegliwości zaprzeczały jednak owemu pragnieniu i wskazywały na dalszy jej rozwój. 14 listopada

\footnotetext{
${ }^{26}$ List z Nieświeża, 21 X 1756, AGAD, AR, dz. IV, sygn. 614, nr 150, k. 136

27 Diariusz Michała Kazimierza Radziwiłła, k. 2022.

${ }^{28}$ List z Nieświeża, 1 XI 1756, AGAD, AR, dz. IV, sygn. 615, nr 152, k. 6.

${ }^{29}$ List z Nieświeża, 3 XI 1756, AGAD, AR, dz. IV, sygn. 615, nr 154, k. 10

${ }^{30}$ List z Nieświeża, 7 XI 1756, AGAD, AR, dz. IV, sygn. 615, nr 155, k. 14.

31 Tamże.
} 
O problemach zdrowotnych magnackich dzieci w XVIII w. na przykładzie...

pisała, że „najprzód w dole wszystka w pęcherzach i wrzodach, w gębie i w nosie pełno krost, $\mathrm{z}$ ucha materyja ciecze, i bardzo się $\mathrm{z}$ nią źle działo"32. Stan wskazany przez Annę dowodzi, że choroba u dziewczynki była już bardzo zaawansowana. $Z$ korespondencji Radziwiłłowej dowiadujemy się, że w trakcie jej trwania dziecko nie dojadało, a więc jak możemy się domyślić - uległa ona odwodnieniu, a jej waga znacznie spadła. Był to efekt postępującej choroby. Wyżej wspomniane pęcherze pojawiały się często w śluzówce jamy ustnej, powodując tym samym ból i niechęć do spożywania pokarmów. Swędzenie, a w związku z nim niecierpliwość oraz płacz powodowały, że dziecko miało duże problemy ze snem $^{33}$. I choć $w$ jednych miejscach pęcherze $\mathrm{z}$ ropą zamieniały się $\mathrm{w}$ zasuszone strupy, to $\mathrm{w}$ innych pojawiały się nowe. Zatroskana o zdrowie i życie matka wyrażała swoje zmartwienie faktem, że „gębę we środku i z wierzchu bardzo osypało” ${ }^{34}$. W trzy tygodnie od wystąpienia pierwszych objawów ciało, głowę oraz twarz dziewczynki pokrywały nie krosty czy pęcherze $\mathrm{z}$ ropą, ale ropiejące wrzody, które zamieniały się w rany oraz dziury. Przypuszczać możemy, że w związku z brakiem właściwej higieny dziewczynka rozdrapywała owe krosty, w takiej sytuacji mogło wkraść się również zaka$\dot{z ̇ e n i e}^{35}$. Nie mając nadziei w lekarzach, Anna zdrowie i życie swojej ukochanej córki powierzyła św. Wincentemu, patronowi wszystkich dzieł miłosierdzia w Kościele katolickim. Niestety, po ponad miesiącu walki o powrót dziecka do zdrowia dziewczynka zmarła 3 grudnia $1756 \mathrm{r}^{36}$ Trudno jednoznacznie stwierdzić, czy przyczyną śmierci była ospa (organizm nie zwalczył infekcji) czy jakieś powikłanie. Skoro Anna pisała o ropiejących wrzodach, to mogło dojść do sepsy. W jej wyniku przestają pracować nerki, a serce jest bardzo obciążone. Ponadto pamiętać należy, że choroba jednego z dzieci stanowiła duże niebezpieczeństwo również dla innych pociech. Warto też podkreślić, że wielokrotnie zagrażała ona samej matce, która niekiedy nie będąc świadomą, pod sercem nosiła kolejne życie.

Obok ospy oraz odry równie niebezpieczne było nagminne zapalenie przyusznic, potocznie zwane ,świnką”. Anna w jednym z listów informowała męża, że ich ośmiomiesięczna córka Maria Wiktoria Szmaragda (ur. 8 sierpnia 1760 r.) zachorowała na pewien „guz”, który roz-

\footnotetext{
${ }^{32}$ List z Nieświeża, 14 XI 1756, AGAD, AR, dz. IV, sygn. 615, nr 157, k. 19.

${ }^{33}$ Tamże.

${ }^{34}$ List z Nieświeża, 21 XI 1756, AGAD, AR, dz. IV, sygn. 615, nr 159, k. 25

${ }^{35}$ List z [?], 27 XI 1756, AGAD, AR, dz. IV, sygn. 615, nr 161, k. 31.

${ }^{36}$ Diariusz Michała Kazimierza Radziwiłła, k. 2077.
} 
ciągnął się „aż na pół szyi i karku”37. Można by zadać pytanie, o jakiej chorobie donosiła mężowi Radziwiłłowa, gdyby nie fakt, że w tej samej wiadomości zapisała, że „wiele dzieci na to teraz chorują" ${ }^{38} . \mathrm{Na}$ tej podstawie można stwierdzić, że „druga Pani na Nieświeżu” pisała o wspomnianej wyżej „śwince”. Interesujący wydaje się być inny fakt wskazany przez Radziwiłłową w korespondencji, a mianowicie sposób leczenia. Polegał on na rozcięciu ,guza”. W tym celu Anna zatrzymała w Nieświeżu cyrulika, który ów zabieg miał wykonaćc ${ }^{39}$. Z listu słanego kilka dni później wynika, że został on przeprowadzony i zakończył się pomyślnie, a w jego efekcie upuszczano „materyje”, czyli zgromadzoną ropę ${ }^{40}$. Z opisu zamieszczonego przez Annę można wnioskować, że wspomniany cyrulik dokonał nacięcia ślinianek, które to podczas choroby ulegają stanowi zapalnemu ${ }^{41}$.

Równie niebezpieczne jak choroby zakaźne bywały infekcje górnych i dolnych dróg oddechowych. Towarzysząca im i utrzymująca się kilka dni wysoka temperatura, a także męczący, a wręcz duszący kaszel występujący zarówno w dzień, jak i w nocy powodował znaczne osłabienie dziecka i narażał je na inne choroby. W jednym z listów Anna donosiła Michałowi, że mającemu półtora roku ich synowi Hieronimowi Wincentemu ${ }^{42}$ podane zostało lekarstwo na „ściągnięcie flegmy z piersi, po którym miał skutek". Podany środek był na tyle skuteczny, że obniżył on znacznie gorączkę, a także wyciszył napady kaszlu $^{43}$. Jak dowiadujemy się z innego listu słanego do „Rybeńki”, druga „pani na Nieświeżu” została zobowiązana do przesłania informacji o stanie zdrowia Hieronima przez swojego męża ${ }^{44}$. Świadczy to $\mathrm{z}$ jednej strony o trosce, jaką wykazał się Michał o jedynego syna z drugiego małżeństwa, z drugiej zaś o pewnej świadomości, jak wielkim niebezpieczeństwem były tego typu infekcje. Zapalenie gardła, oskrzeli i płuc powodowało, że dzieci, podobnie jak w przypadku chorób zakaźnych, traciły łaknienie, to zaś groziło utratą masy i odwodnieniem, co w gruncie rzeczy przekładało się na utratę odporności.

\footnotetext{
${ }^{37}$ List z Nieświeża, 9 IV 1761, AGAD, AR, dz. IV, sygn. 618, nr 343, k. 106.

${ }^{38}$ Tamże.

39 Tamże, k. 106-107.

${ }^{40}$ List z Nieświeża, 25 IV 1761, AGAD, AR, dz. IV, sygn. 618, nr 346, k. 114.

${ }^{41}$ List z Nieświeża, 1 V 1761, AGAD, AR, dz. IV, sygn. 618, nr 347, k. 117.

${ }^{42}$ Pełne imię syna Anny i „Rybeńki” brzmiało: Hieronim Wincenty Mamertus Anthemus Maximus, zob. Diariusz Michała Kazimierza Radziwiłła, k. 2230.

${ }^{43}$ List z Nieświeża, 16 XII 7160, AGAD, AR, dz. IV, sygn. 618, nr 333, k. 80.

${ }^{44}$ List zaczyna dość wymownymi słowami „Czyniąc zadość rozkazowi Panu i Dobrodziejowi mego nie omieszkam donosić o zdrowiu syna naszego [...]”, List z Nieświeża, 18 XII 1760, AGAD, AR, dz. IV, sygn. 618, nr 334, k. 82.
} 
O problemach zdrowotnych magnackich dzieci w XVIII w. na przykładzie...

O ile w przypadku pociech powyżej pierwszego roku życia można było jakoś tej sytuacji zaradzić, o tyle w przypadku noworodków stawało się to bardzo niebezpieczne i zagrażające ich życiu. Negatywne efekty wynikające $\mathrm{z}$ zachorowania dziecka na infekcję dróg oddechowych można było dostrzec już po kilku dniach. W cztery dni od podania Hieronimowi lekarstw Anna pisała „Rybeńce”, że ich syn choć wraca do zdrowia, to jest „mizerny bardzo nieboraczek, ciało ma takie miętkie jak chorążyna" ${ }^{5}$. Ponadto pamiętać należy, że większość infekcji ma charakter wirusowy, których i dziś nie leczy się antybiotykami. Jednak część z nich prowadzi do nadkażeń, a wówczas nawet niegroźna dla ludzkiego organizmu bakteria może doprowadzić do kolejnej choroby $-\mathrm{z}$ tym aspektem ówczesna medycyna nie potrafiła sobie poradzić.

Analiza materiału źródłowego pozwala stwierdzić, że obok chorób zakaźnych oraz dróg oddechowych dzieci Michała i Anny dość często zmagały się z „fybrą" 46 . Taki stan rzeczy wynikał m.in. z faktu, że odporność dziecka dojrzewa do 7. roku życia. Były one zatem szczególnie na nią narażone. $\mathrm{W}$ jednym $\mathrm{z}$ listów Radziwiłłowa informowała męża, że „Maciulka znowu fybra opuściła, ale nie wiem na jak długo, bo się już 9 razy wracała [...]" ${ }^{\text {47 }}$. W innym zaś donosiła, że Tosia „,...] to nie wiem, co z niej będzie, bo jej fybra nie ustaje, a nogi jej bardzo spuchły i żołądek" ${ }^{48}$. Niestety materiał źródłowy nie pozwala stwierdzić, co wywoływało ową gorączkę i dreszcze, które były objawem całej gamy różnorodnych schorzeńn ${ }^{49}$. Nie wiemy również, jakie podejmowano działania w celu zahamowania objawów oraz jak zapobiegano ewentualnym nawrotom. Częstotliwość występowania febry pozwala stwierdzić, że była to choroba dość powszechna, której z całą pewnością nie należało bagatelizować. To jeden $\mathrm{z}$ jej objawów, a mianowicie gorączka budziła największy strach wśród rodziców, zwłaszcza gdy występowała ona bez dodatkowych objawów lub stanowiła powikłanie po niedoleczonej wcześniej jakiejś infekcji. Przypomnijmy, że właśnie z powodu gorączki niewiadomego pochodzenia zmarł ukochany pierwszy syn Michała

\footnotetext{
45 List z Nieświeża, 21 XII 1760, AGAD, AR, dz. IV, sygn. 618, nr 336, k. 87.

46 Febra (łac. febris) - choroba ta zaczyna się od przeciągania, ziewania i pragnienia, dręczy po tym przykrym zimnem, roztaczającym drżenie po całym ciele, a kończy swój paroxyzm na bólu głowy i gorączce. Powoduje ją bieg gwałtowny i niepożądany krwi, zob. S.B. Linde, Słownik Języka Polskiego, t. 1, Warszawa 1807, s. 635.

47 List z Nieświeża, 15 VI 1754, AGAD, AR, dz. IV, sygn. 613, nr 165, k. 17.

${ }^{48}$ List z Nieświeża, 19 VI 1757, AGAD, AR, dz. IV, sygn. 615, nr 186, k. 96.

${ }^{49}$ K. Zuba, Michat Kazimierz Radziwiłt (1702-1762), dz. cyt., s. 61.
} 
i Franciszki - Janusz Tadeusz ${ }^{50}$, nie wspominając o tym, że to właśnie gorączka przyczyniła się do śmierci samego „Rybeńki” ${ }^{51}$. Warto dodać, że w diariuszu „Rybeńki” „febry” opisywane były za pomocą określników, np. „continua” (ciągły, nieprzerwanie utrzymujący się stan gorączkowy), „tertiana” (co trzy dni, postać trzydniowej gorączki), „quartana” (co cztery dni, postać czterodniowej gorączki). Nie odnajdujemy owych określników w listach Anny. Możemy się jedynie domyślać, że skoro febra wracała co kilka dni, to znaczy, że prawdopodobnie dziecko chorowało na malarię, zwaną zimnicą. Chorobę tę wywołują ukąszenia komarów, których największy wylęg przypada na kwiecień i maj (niekiedy czerwiec) ${ }^{52}$. Przypomnijmy, że Anna o nawracających się febrach u dzieci donosiła „Rybeńce” $\mathrm{z}$ reguły na przełomie maja i czerwca. W przypadku „Tosi” sprawa była bardziej skomplikowana. Prawdopodobnie u dziewczynki, w wyniku przebytej „trzeciaczki”, doszło do powikłań. Jednym z objawów jest powiększenie śledziony, które pacjent odczuwa jako ból żołądka oraz wzdęcie nadbrzusza ${ }^{53}$.

Do kolejnej grupy chorób należy zaliczyć problemy natury gastryczno-żołądkowej. Prawdopodobnie ich występowanie wynikało z jednej strony ze stosowanej diety, która będąc ubogą w warzywa oraz owoce, doprowadzała do zaburzeń przemiany materii, z drugiej zaś z braku higieny i spożywania potraw przygotowanych w różnych warunkach, często także z dzikich zwierząt. Dzieci Anny i Michała dość często zatem zmagały się raz z biegunkami, którym towarzyszyły wymioty, bóle żołądka oraz gorączka, innym razem z zaparciami. Te pierwsze były niebezpieczne, bo doprowadzały do odwodnienia, te drugie niestety mogły skutkować w późniejszym czasie wystąpieniem hemoroidów ${ }^{54}$. W celu oczyszczenia dzieciom podawano bliżej nieokreślone lekarstwo na „laksacyją” lub też karmiono rosołem ${ }^{55}$. Syn Radziwił-

\footnotetext{
${ }^{50} \mathrm{~W}$ diariuszu Michał Kazimierz pod datą 7 października odnotował: „Odebrałem wiadomość z Ołyki, że syn mój Janusz na gorączkę ciężko zachorował [...]”, zob. Diariusz Michała Kazimierza Radziwiłła, k. 1751. Cztery dni później zapisał: „[...] moi ludzie odebrali, że dnia 10 praesentis o trzeciej z południa syn mój najmilszy Janusz Radziwiłł Bogu i Stwórcy swemu ducha oddał [...]”, tamże, k. 1752.

51 B. Manyś, Uroczystości rodzinne w Wilnie za panowania Augusta III, Poznań 2014, s. 202-203.

${ }_{52}$ K. Zuba, Michat Kazimierz Radziwitt (1702-1762), s. 60-61.

53 Tamże, s. 62.

${ }^{54}$ Tamże, s. 65.

${ }^{55}$ List z Nieświeża, 17 III 1760, AGAD, AR, dz. IV, sygn. 618, nr 304, k. 7. Warto zauważyć, że rosół zawiera kolagen i żelatynę, które mają korzystny wpływ na błonę śluzową żołądka. Zawarta w rosole glutamina wspiera procesy odbudowy uszkodzonych komórek w przewodzie pokarmowym. Bulion wspomaga leczenie refluksu oraz zgagi.
} 
O problemach zdrowotnych magnackich dzieci w XVIII w. na przykładzie...

łów Hieronim Wincenty w kwietniu 1760 r., a więc mając niespełna rok, walczył z konstypacjami, czyli zaparciami. Tym zaś towarzyszyła niebezpieczna gorączka ${ }^{56}$.

Posiadamy informacje, że radziwiłłowskie dzieci zmagały się z pasożytami w układzie pokarmowym. W jednym $\mathrm{z}$ listów czytamy, że z dwuletniego Hieronima „wyszedł [...] robak żywy dłużyny blisko półtor[e]j ćwierci [...]" 57 . Po wielkości pasożyta, a raczej jego długości możemy przypuszczać, że Hieronim chorował na glistnicę. Taki stan rzeczy nie powinien nas dziwić. Do zarażenia tym największym ze znanych jelitowych nicieni najczęściej dochodzi (po dziś dzień) w wyniku niskiego poziomu higieny oraz zaniedbań w gospodarowaniu ściekami. W XVIII w. nietrudno zatem było w przypadku dzieci ani o glistnice, ani o owsiki. Przypomnijmy jedynie, że po zarażeniu w przewodzie pokarmowym z jaj uwalniają się larwy, które przedostają się przez śluzówkę jelit do krwi, a z tą do wątroby i płuc. Przemieszczają się do pęcherzyków płucnych, a następnie przez oskrzeliki i oskrzela do gardła, przy odkrztuszaniu są połykane. Trafiają ponownie do przewodu pokarmowego, w którym dochodzi do tzw. wylinki larw, czyli przekształcenia w postać dojrzałą pasożyta. Warto dodać, że faza jelitowa inwazji trwa od 10 do 24 miesięcy. Glistnica może doprowadzić do niedrożności jelita lub zespołu złego wchłaniania. W okresie tzw. wędrówki larw u chorego mogą wystąpić: suchy kaszel, bóle klatki piersiowej oraz stany podgorączkowe. U dzieci bardzo często występowało niedożywienie oraz bóle brzucha. W tej sytuacji pojawia się pytanie, czy drobne infekcje, jakie występowały u Hieronima Wincentego, zwłaszcza zaś okresowe gorączki oraz zaparcia nie były skutkiem żyjącego w maleńkim organizmie pasożyta? To pytanie musi pozostać jednak bez odpowiedzi.

Stwierdzić należy, że najwięcej miejsca Anna poświęcała opisom chorób, z którymi zmagały się najmłodsze dzieci. Taki stan rzeczy nie wynikał z faktu, że tylko one znajdowały się w zasięgu jej zainteresowań, a raczej z tego, że to one były najbardziej narażone na infekcje, choroby, a w ich wyniku na śmierć. Wydaje się, że kluczowe były dwa pierwsze lata, w których to kształtował się system odporności, a dzieci nabierały coraz większej samodzielności, nie tylko w chodzeniu czy mówieniu, ale także w posługiwaniu się widelcem przy stole, o czym raczyła informować swego męża druga ,pani na Nieświeżu”.

Magnackie dzieci, podobnie jak każde inne, były narażone na choroby zarówno przenoszone drogą kropelkową, jak i pasożyty. Warto

${ }^{56}$ List z Nieświeża, 18 IV 1760, AGAD, AR, dz. IV, sygn. 618, nr 308, k. 17.

57 List z Nieświeża, 16 V 1761, AGAD, AR, dz. IV, sygn. 619, nr 354, k. 11. 
podkreślić, że czynników warunkujących wystąpienie czy też zarażenie się jednym lub drugim było kilka: niski poziom higieny można zaliczyć do kluczowych, podobnie jak zła - czy raczej uboga dieta, a także stan wiedzy medycznej. $\mathrm{O}$ ile materiał źródłowy przekazuje dość sporo informacji o chorobach, o tyle niewiele wiadomo o sposobie ich leczenia czy zapobiegania. Czujność opiekunów zwiększała szanse na wyzdrowienie pociech, jednak słaba znajomość fizjologii człowieka, ograniczona wiedza o pochodzeniu chorób (w pierwszej kolejności, czy ma ona podłoże genetyczne czy też środowiskowe) oraz wspomniany już wielokrotnie niski poziom higieny utrudniały leczenie i powrót do zdrowia. Dostępne źródła wskazują, że Radziwiłłowie dokładali wszelkich starań, aby ich potomstwo czuło się dobrze i z troską pochylali się nad najdrobniejszymi niedomaganiami, obawiając się, nie bez przesady, ich konsekwencji.

W kontekście powyższych rozważań rodzi się jednak pytanie, czy w wyniku tak licznych ciąż na świat przychodziły zdrowe dzieci? Bez odpowiedzi pozostaje również kwestia, na ile przebyte choroby w dzieciństwie wpływały na dalszy rozwój magnackich dzieci i skutkowały osłabionym systemem odporności w życiu dorosłym.

Warto zwrócić uwagę na jeszcze jeden aspekt, mianowicie niewielką liczbę doniesień o zachorowaniach dzieci z drugiego małżeństwa W diariuszu „Rybeńki”. W tym przypadku rzecz przedstawia się zupełnie inaczej niż w odniesieniu do latorośli zrodzonych z Franciszki Urszuli. Taki stan rzeczy wynikał z pewnością z wielu czynników. Pamiętać należy, że w chwili narodzin pierwszej córki z drugiego małżeństwa Michał Kazimierz był człowiekiem dojrzałym, który związek małżeński zawarł m.in. z przyczyn prokreacyjnych. Wydaje się zatem, że dla „Rybeńki” istotne było spłodzenie syna, a kwestie związane z utrzymaniem powitych dzieci przy życiu należały do Anny, która raczej była żoną z „rozsądku”, a nie z „miłości”.

\section{Bibliografia}

\section{Literatura przedmiotu:}

Archiwum Główne Akt Dawnych, Archiwum Radziwiłłowskie:

dz. IV, sygn. 613, nr 63, 165,

dz. IV, sygn. 614, nr 150,

dz. IV, sygn. 615 , nr 152, 154, 155, 157, 159, 161, 186,

dz. IV, sygn. 616, nr 220, 
O problemach zdrowotnych magnackich dzieci w XVIII w. na przykładzie...

dz. IV, sygn. 618, nr 304, 308, 333, 334, 336, 343, 346, 347,

dz. IV, sygn. 619, nr 354,

dz. VI, sygn. II-80a.

Bajer J., Mariani A., Macocha idealna: aktywność Anny Luizy z Mycielskich Radziwiłtowej $w$ świetle francuskiej korespondencji dyplomatycznej (1764-1765), „Studia Europaea Gnesnensia” 2014, t. 10.

Brink J.R., Female Scholars: A Tradition of Learned Women Before 1800, Montreal 1980.

Dymnicka-Wołoszyńska H., Radziwiłłowa Anna Ludwika (1729-1771), PSB, t. 30.

E. de Goncourt, de Goncourt J., La Femme au XVIIIe siècle, Paris 1882.

Fesser D., Nieznany wiersz Anny z Mycielskich Radziwitłowej, „Terminus" 2016, t. 18, z. 3(40).

Gad P., Zagraniczna podróż młodego magnata w świetle diariusza Michała Kazimierza Radziwiłła „Rybeńki”, [w:] B. Mazurkowa (red.), Codzienność i niecodzienność oświeconych, cz. 2: W rezydencji, w podróży i na scenie publicznej, Katowice 2013.

Gray C., Women Writers and Public Debate in 17th-Century Britain, Palgrave Macmillan 2007.

Jakuboszczak A., Manyś B., Obraz matżeństwa Anny z Mycielskich i Michała Kazimierza Radziwiłła „Rybeńki” w listach „drugiej pani na Nieświeżu" z lat 1754-1762, [w:] B. Manyś, M. Zwierzykowski (red.), Wokót Wielkiego Księstwa Litewskiego i jego tradycji, Poznań 2016.

Jakuboszczak A., Sarmacka dama: Barbara Sanguszkowa (17181791) i jej salon towarzyski, Poznań 2008.

Jankowski R., Śmierć matki i bliskich Michała Kazimierza Radziwiłła „Rybeńki” (1702-1762) w świetle jego diariusza, „Miscellanea Historico-Archivistica” 2015, t. 22.

Judkowiak B., Arystokratyczna tożsamość ksiażąt nieświeskich $w$ świetle obrazów literackich i teatralnych. W kręgu twórczości Franciszki Urszuli Radziwitłowej, [w:] Socialiniu tapatumu reprezentacijos Lietuvos Didžiosios Kunigaikštystės kultūroje, t. 4, Vilnius 2010.

Judkowiak B., Franciszka Urszula Radziwiłłowa - w poszukiwaniu własnego głosu. Propozycje interpretacyjne, dokumentacyjne i edytorskie, Poznań 2013. 
Kaczorowski W., Choroby i prawdopodobna przyczyna zgonu Zygmunta III Wazy, „Archiwum Historii Medycyny” 1982, t. 45, z. 1/4.

Kaczorowski W., Choroby i prawdopodobne przyczyny śmierci żon Zygmunta III Wazy - Anny i Konstancji, „Studia Historyczne” 1993, z. 3.

Kowalczyk M.E., „Żona śliczna, poczciwa i wszelkich cnót petna”, czyli historia życia Anny Ludwiki z Mycielskich u boku dwóch Radziwiłtów (Leona Michała, a po jego śmierci Michała Kazimierza „Rybeńko”), [w:] M. Nagielski, K. Żojdź (red.), Radziwiłłowie w stużbie Marsa, Warszawa 2017.

Kuchowicz Z., Jeszcze o zdrowiu i niezdrowiu magnatów XVII-XVIII w., „Kwartalnik Historyczny” 1970, R. 77, z. 2.

Kuchowicz Z., Przyczyny śmierci Barbary Radziwiłłówny, „Archiwum Historii Medycyny” 1975, t. 38, z. 2.

Kuchowicz Z., Z badań nad stanem biologicznym społeczeństwa polskiego od schytku XVI do końca XVIII w., Łódź 1972.

Liedke M., Demografia rodziny magnackiej w Wielkim Księstwie Litewskim na tle elit zachodnioeuropejskich. Wybrane problemy, „Przeszłość Demograficzna Polski” 2015, 37, nr 1.

Linde S.B., Stownik Języka Polskiego, t. 1, Warszawa 1807.

Manyś B., „Jak się ty tam dziś będziesz weselić, to i ja tu będę wesoła”. O świętach i świętowaniu w korespondencji Anny z Mycielskich Radziwiłłowej z lat 1754-1762, [w:] E. Kościk, F. Wolański, R. Żerelik (red.), Staropolski oglą świata. Nulla dies sine linea. Ksiegga jubileuszowa dedykowana profesorowi Bogdanowi Rokowi w 70. rocznicę urodzin, Toruń 2017.

Manyś B., Radości i troski Anny z Mycielskich Radziwiłłowej w listach do męża Michała Kazimierza Radziwitła „Rybeńki”, [w:] B. Popiołek, U. Kicińska, A. Słaby (red.), Kobiece kregi korespondencyjne w XVII-XIX wieku, Warszawa 2016.

Manyś B., Uroczystości rodzinne w Wilnie za panowania Augusta III, Poznań 2014.

Mariani A., O XVIII-wiecznych praktykach łowieckich $w$ świetle diariusza księcia Michała Kazimierza Radziwiłła „Rybeńki”, [w:] T.J. Żuchowski (red.), Europejskie tradycje towieckie. Tom wydany $z$ okazji III Międzynarodowego Kongresu Kultury Łowieckiej, Warszawa 2014.

Mariani A., Podróż zagraniczna Michała Kazimierza Radziwiłła „Rybeńki” (1721-1723). Między tożsamościa rodowa a poczuciem przy- 
O problemach zdrowotnych magnackich dzieci w XVIII w. na przykładzie...

należności do arystokracji europejskiej, [w:] M. Dębowski, A. Grześkowiak-Krwawicz, M. Zwierzykowski (red.), Europejski wiek osiemnasty: uniwersalizm myśli, różnorodność dróg, Kraków 2013.

Martin J.-C., La Révolte brisée. Femmes dans la Révolution française et l'Empire, Paris 2008.

Michalski J., Radziwiłt Karol Stanisław zw. Panie Kochanku (17341790), PSB, t. 30.

Muszyńska A., Starania Michała Kazimierza Radziwiłła „Rybeńki” o ręke Marii Zofii z Sieniawskich, [w:] B. Mazurkowa (red.), Codzienność i niecodzienność oświeconych, cz. 2: $W$ rezydencji, w podróży i na scenie publicznej, Katowice 2013.

Pietrzak J., Dziedzic królewskiej purpury. Stowo i obraz w propagandowych działaniach Michała Kazimierza Radziwiłła „Rybeńki” względem przejęcia dziedzictwa Sobieskich, „Zeszyty Naukowe Towarzystwa Doktorantów UJ. Nauki Społeczne” 2016, nr 4, z. 3.

Ragauskienė R., Mirties nugalèti nepavyko: Biržu ir Dubingiu kunigaikščiu Radvilu biologine istorija (XV a. pabaiga-XVII a.), Vilnius 2017.

Rostworowski E., Zdrowie i niezdrowie polskich magnatów w XVIXVIII w., „Kwartalnik Historyczny” 1969, R. 76, z. 4.

Podróże litewskiego magnata do Gdańska, Człuchowa, a nawet i dalej... Fragmenty „Diariusza” Michała Kazimierza Radziwiłła „Rybeńki” z lat 1721, 1737 i 1752, wyd. J. Dygdała, Warszawa 2013.

Smith H., Reason's disciples: seventeenth-century English feminists, Chicago \& London 1982.

Stuurman S., François Poulain de la Barre and the Invention of Modern Equality, Cambridge, MA and London 2004.

Suchodolska E., Radziwiłłowski tłok pieczętny $z$ drugiej połowy XVIII wieku, „Studia Źródłoznawcze” 1997, t. 36.

Veličkaitė V., Apie Radvilos Žuvelès meile Uršulei. Dienoraščio liudijimai, „Liaudies kultūra” 2017, nr 2.

Veličkaitè V., Lietuvos Didžiosios Kunigaikštystès didiko Mykolo Kazimiero Radvilos-Žuvelès kelionès jo dienoraščio duomenimis, „Darbai ir Dienos” 2015, nr 64.

Veličkaitė V., Mykolo Kazimiero Radvilos Žuvelès piligrimystė XVIII a., „Liaudies kultūra” 2017, nr 5.

Veličkaitė V., Mykolo Kazimiero Radvilos, vadinamo Žuvele (17021762) dienoraštis: tarp itinerarijo ir egodokumento, Bibliotheca Lituana IV: Privačioji raštija ir egodokumentinis paveldas, 2017. 
Wierzbicka-Michalska K., Radziwiłtowa Franciszka Urszula (17051753), PSB, t. 30.

Zielińska T., Więź rodowa domu Radziwiłłowskiego w świetle diariusza Michała Kazimierza Radziwiłła „Rybeńki”, Miscellanea Historico-Archivistica, 3: Radziwiłtowie XVI-XVIII wieku. W kręgu polityki i kultury, Warszawa-Łódź 1989.

Ziembicki W., Zdrowie i niezdrowie Jana Sobieskiego. Studium historyczno-lekarskie z uwzględnieniem nieznanego diariusza, „Archiwum Historii i Filozofii Medycyny oraz Historii Nauk Przyrodniczych” 1930, cz. 1, t. X, z. 2.

Zuba K., Bogusław Radziwitt (1620-1669) - portret psychofizyczny magnata w świetle listów i pamiętników, „Medycyna Nowożytna. Studia nad Kulturą Medyczną” 1998, t. 5, z. 1.

Zuba K., Michat Kazimierz Radziwitt (1702-1762) - portret psychologiczny, „Medycyna Nowożytna. Studia nad Kulturą Medyczną” 2002, t. 9, z. 1-2.

Zuba K., O tym jak „Rybeńkę” leczono. Kuracje i zabiegi medyczne Michała Kazimierza Radziwiłła (1702-1762), „Medycyna Nowożytna. Studia nad Kulturą Medyczną” 2001, t. 8, z. 1.

\section{Summary \\ Health problems of magnate children in the 18th century on the example of Michał Kazimierz Radziwiłł "Rybeńko" and Anna from Mycielski Radziwiłł}

This article was created in order to characterize diseases and ailments that the magnates ` children were struggling in the XVIII c.

From this angle were analyzed the complaints which occurred in children of one of the most important representatives of the Lithuanian magnate - Michał Kazimierz Radzivill "Rybeńka” and his second wife Anna from Mycielski Radzivill.

So far, in the Polish and Lithuanian historiography, issues related to the health of the most the richest were analyzed only in the context of adults. The basis of these considerations is the correspondence of the "other Lady of Nieśwież", kept in the Central Archives of Historical Records. It has a special meaning because the letters of "Rybeńka" to Anna have not been preserved. In addition, was used the diocese of the hetman of Grand Duchy of Lithuania, which is in the same archive. On the basis of the collected matter, were analyzed the source mentions informing us about: symptoms of diseases and occurring infections, their course, type and treatment applied. 